\title{
Part time senior registrars, registrars, and senior house officers in general medicine and its specialties: a report to the Royal College of Physicians
}

\author{
C W BURKE, N A BLACK
}

\section{Introduction}

The Department of Health and Social Security introduced schemes for part time training in 1969 and 1976 aimed at improving the use of the growing number of women medical graduates especially; the current scheme is set out in DHSS personnel memorandum PM(79)3.

The Oxford region, under the inspiration of Dr E Rosemary Rue, has been the leader in implementing these schemes. The Oxford regional advisers of the Royal College of Physicians have thus had particular concern over the difficulties, and called attention to them at a meeting of college regional advisers in 1976-7 and again in 1979-80. On this last occasion the meeting of regional advisers, supported by the president, responded by commissioning a survey of the problems in general medicine and its subspecialties in England, Wales, and Northern Ireland, which was carried out by us in 1981. A preliminary report was made to the regional advisers in October 1981, but because of its length and subsequent receipt of further data and more research, we now present this final and shortened report to the college for action.

\section{Method}

Specialists in community medicine dealing with medical staffing in the 14 English regions, Wales, and Northern Ireland were sent a questionnaire on the numbers of registrars, senior house officers, and senior registrars in training under $P M(79) 3$, and the number of sessions worked, in general medicine and its subspecialties (excluding neurology and haematology, and community medicine). Clinical assistants and women on the retainer scheme were excluded as these are not training posts. Information was not sought on part time university or soft money posts, so our figures underestimate those in "training" in the broader sense. Armed with the returns from specialists in community medicine regional advisers were given a questionnaire on educational approval and appointments procedure; they were also asked to identify the trainees and administer to them a third questionnaire, which was returned to us anonymously (though we noted the region of origin from the postmark). This trainee questionnaire dealt with personal statistics, previous experience, appointment procedure, educational supervision, and various aspects of the quality of training.

\section{Results}

\section{PART I: SENIOR REGISTRARS}

In five regions the regional advisers had the greatest difficulty in locating the senior registrars and confirming the returns from

\section{Radcliffe Infirmary, Oxford OX2 6HE}

C W BURKE, DM, FRCP, former Oxford regional adviser N A BLACK, MB, DRCOG, senior registrar in community medicine

Correspondence to: Dr C W Burke, The Radcliffe Infirmary, Oxford OX2 $6 \mathrm{HE}$. the specialists in community medicine, which itself points to defects in the PM(79)3 scheme. The final concordant figures for the different regions are in table I.

The specialty distribution of the 47 senior registrars is shown in table II. Twenty of them are in paediatrics; 13 returned questionnaires, of whom only three had been appointed after the first PM(79)3 advertisements in September 1980, so between 10 and 17 are probably unknown to central manpower authorities.

TABLE I-Verified part time training posts

\begin{tabular}{lcc}
\hline & $\begin{array}{c}\text { Senior } \\
\text { registrars }\end{array}$ & $\begin{array}{c}\text { Registrars/ } \\
\text { senior house } \\
\text { officers* }\end{array}$ \\
\hline England by region: & 3 & \\
Northern & 3 & 10 \\
Yorkshire & 6 & 5 \\
North Western & 3 & 2 \\
Mersey & 5 & 1 \\
Trent & 3 & 2 \\
West Midlands & 6 & 24 \\
Oxford & 3 & 8 \\
East Anglian & 2 & 5 \\
North East Thames & 1 & 10 \\
North West Thames & 3 & 3 \\
South East Thames & 2 & 5 \\
South West Thames & 2 & 4 \\
Wessex & 0 & 3 \\
South Western & 2 & 1 \\
Wales & 3 & 93 \\
Northern Ireland & 47 & \\
\hline Total & & \\
\hline * Roughly two thirds are registrars, but the senior house \\
*ficers' experience and age was similar.
\end{tabular}

TABLE II-Verified part time training posts by specialty

\begin{tabular}{lcc}
\hline Specialty & $\begin{array}{c}\text { Senior } \\
\text { registrars }\end{array}$ & $\begin{array}{c}\text { Registrars/ } \\
\text { senior house } \\
\text { officers }\end{array}$ \\
\hline General (internal) medicine & 3 & 13 \\
Cardiology* & 1 & 0 \\
Chest medicine* $^{\text {Clinical immunology* }}$ & 3 & 1 \\
Clinical pharmacology* $_{\text {Continuing care** }}^{*}$ & 0 & 1 \\
Gastroenterology* & 1 & 1 \\
Renal medicine* & 0 & 0 \\
Rheumatology/rehabilitation* & 1 & 1 \\
\hline Total & 1 & 23 \\
\hline Dermatology & 11 & 8 \\
Venereology & 6 & 8 \\
\hline Total & 4 & 16 \\
\hline Geriatrics & 10 & 19 \\
Paediatrics & 6 & 35 \\
\hline Total & 20 & 93 \\
\hline
\end{tabular}

* Some of these posts included general internal medicine.

There are defects still in the method of appointment of part time senior registrars, though $\operatorname{PM}(79) 3$ is an improvement on previous schemes. Under paragraph three of the memorandum there should be $(a)$ opportunities for part time senior registrar training in all specialties, and $(b)$ manpower control. These objectives are clearly served. Paragraph (3) (c), however, states that part time senior registrars should be assessed by the same criteria as full time, and (3) $(d)$ that there should be competition 
between candidates to ensure fairness. These objectives are not, according to our survey, fulfilled. Table III shows that even since PM(79) 3 came into effect with the national advertisements of October 1980, five of 10 people appointed stated that they had not been appointed at an advisory appointments committee. Moreover, even where there was an advisory appointments committee the college was seldom represented, unlike advisory appointments committees for full time senior registrars (table III). This representation was absent in six regions, and in one (North Western) it has been refused. PM(79)3 states (in its annex A) that there should be an advisory appointments committee in all cases, though it negates the need for college representation on it if the applicant has been before the national assessment committee; yet only where the number of applicants exceeds manpower spaces does this national committee assess the applicant's qualifications, and our results suggest that this assessment, when it does occur, has more to do with manpower than merit. Moreover, only in 31 out of 47 cases had an external assessment been made of the applicant's general professional training as being suitable for entering the senior registrar grade. Further, our experience of these advisory appointments committees (in the Oxford region) shows that consultant and lay members alike are baffled by the appearance of only one candidate and are unsure whether to appoint on philanthropic or competitive grounds. This disparity between standards is a disservice to both trainees and the scheme itself.

Despite these loopholes in appointment procedure, 34 of 47 posts carried approval from the Joint Committee for Higher Medical Training (table III), and 26 of the 30 responding trainees had the membership of the Royal College of Physicians (table IV). Their previous experience was commensurate with that of full timers, with a mean of three and a half years' whole time equivalent in the specialty (table IV). Twenty two of the 30 had three years' whole time equivalent professional training in respectable looking registrar or senior house officer posts or both that should have carried adequate general and acute experience, so their experience (in the subjective opinion of CWB) could have enabled them to be shortlisted for a full time senior registrar post (table IV). The study content of many, but not all, posts was adequate (table IV) (although in two cases study leave had been refused). The main deficiency of these posts was the acquisition of acute and on call experience, with only 11 of 22 posts outside dermatology and venereology giving it. The reasons for this were varied, ranging from obstruction by full time colleagues to excessive non-medical commitment. In dermatology and venereology this was less of a problem. We consider that the right time to consider the balance between the availability of acute experience and the trainee's ability to undertake it is before appointment, and we would like to see regional advisers take more part in the preappointment counselling of part time senior registrars in the acute specialties. By the time the holder has. been in post for a year and the post inspected by the Joint Committee for Higher Medical Training it is too late (it is often said that the committee will not inspect until the post is occupied, but the trainee has difficulty getting the post created before approval is obtained). Further, more effort should be made to ensure inspection, to ensure visible comparability with full time posts. A further difficulty reinforces this for part time senior registrars: unlike with their full time colleagues, most of their posts seem to be in non-teaching hospitals, and several of the 30 reported that this was an educational problem.

There were some senior registrars of more than mature years, including four who had clearly served their time in higher

TABLE III-Regional advisers' information on appointments procedures and educational assessment

\begin{tabular}{|c|c|c|c|c|c|c|c|c|c|c|}
\hline & \multicolumn{2}{|c|}{$\begin{array}{l}\text { General (internal) } \\
\text { medicine and } \\
\text { subspecialties }\end{array}$} & \multicolumn{2}{|c|}{ Geriatrics } & \multicolumn{2}{|c|}{ Paediatrics } & \multicolumn{2}{|c|}{$\begin{array}{l}\text { Dermatology and } \\
\text { venereology }\end{array}$} & \multicolumn{2}{|c|}{ Total } \\
\hline & $\begin{array}{l}\text { Senior } \\
\text { registrar }\end{array}$ & $\begin{array}{c}\text { Registrars/ } \\
\text { senior } \\
\text { house } \\
\text { officers }\end{array}$ & $\begin{array}{l}\text { Senior } \\
\text { registrars }\end{array}$ & $\begin{array}{c}\text { Registrars / } \\
\text { senior } \\
\text { house } \\
\text { officers }\end{array}$ & $\begin{array}{l}\text { Senior } \\
\text { registrars }\end{array}$ & $\begin{array}{l}\text { Registrars/ } \\
\text { senior } \\
\text { house } \\
\text { officers }\end{array}$ & $\begin{array}{l}\text { Senior } \\
\text { registrars }\end{array}$ & $\begin{array}{c}\text { Registrars/ } \\
\text { senior } \\
\text { house } \\
\text { officers }\end{array}$ & $\begin{array}{c}\text { Senior } \\
\text { registrars }\end{array}$ & $\begin{array}{c}\text { Registrars/ } \\
\text { senior } \\
\text { house } \\
\text { officers }\end{array}$ \\
\hline $\begin{array}{l}\text { No in training } \\
5 \text { plus } 1 \text { (study) sessions or more } \\
\text { Appointment or review committee held* } \\
\text { College represented at advisory appointments }\end{array}$ & $\begin{array}{c}11 \\
8 \\
7 *\end{array}$ & $\begin{array}{r}23 \\
14 \\
8\end{array}$ & $\begin{array}{l}6 \\
2 \\
5^{*}\end{array}$ & $\begin{array}{r}19 \\
15 \\
9\end{array}$ & $\begin{array}{l}20 \\
13 \\
13^{*}\end{array}$ & $\begin{array}{r}35 \\
19 \\
8\end{array}$ & $\begin{array}{c}10 \\
6 \\
5^{*}\end{array}$ & $\begin{array}{r}16 \\
13 \\
8\end{array}$ & $\begin{array}{l}47 \\
29 \\
30^{*}\end{array}$ & $\begin{array}{l}93 \\
61 \\
33\end{array}$ \\
\hline $\begin{array}{l}\text { committee } \\
\text { Assessment of previous general training by }\end{array}$ & 0 & Not known & 2 & Not known & 6 & Not known & 3 & Not known & 11 & Not known \\
\hline $\begin{array}{l}\text { educational adviser as satisfactory } \\
\text { Joint Committee for Higher Professional } \\
\text { Training approval (senior registrars) or } \\
\text { general professional training approval }\end{array}$ & 8 & - & 1 & - & 16 & - & 6 & - & 31 & 一 \\
\hline $\begin{array}{l}\text { (registrars/senior house officers) } \\
\text { Educational approval refused }\end{array}$ & $\begin{array}{r}10 \\
0\end{array}$ & $\begin{array}{l}4 \\
0\end{array}$ & $\begin{array}{l}4 \\
0\end{array}$ & $\begin{array}{r}2 \\
10\end{array}$ & $\begin{array}{r}13 \\
0\end{array}$ & $\begin{array}{l}1 \\
3\end{array}$ & 7 & $\begin{array}{l}2 \\
2\end{array}$ & $\begin{array}{r}34 \\
1\end{array}$ & $\begin{array}{r}9 \\
15\end{array}$ \\
\hline Not inspected for educational approval & 1 & 19 & 2 & 7 & 7 & 31 & 2 & 12 & 12 & 69 \\
\hline
\end{tabular}

* In the case of senior registrars this has been required only since PM(79)3 came into effect in October 1980 . Five of 10 senior registrars appointed since, and returning questionnaires, had no advisory appointments committee.

TABLE IV-Part time senior registrars' personal questionnaires

\begin{tabular}{|c|c|c|c|c|c|}
\hline & $\begin{array}{l}\text { General (internal) } \\
\text { medicine and } \\
\text { subspecialties }\end{array}$ & Geriatrics & Paediatrics & $\begin{array}{c}\text { Dermatology and } \\
\text { venereology }\end{array}$ & Total \\
\hline $\begin{array}{l}\text { No of replies } \\
\text { Age now (median) (range) } \\
\text { Age at completion of } 4 \text { year WTE* in senior registrar grade } \\
\text { Previous full time work (years) (mean) } \\
\text { Previous years in specialty (mean WTE) } \\
3 \text { years WTE general professional training and shortlistable (see text) } \\
\text { MRCP } \\
\text { MD } \\
\text { Other qualification-for example, DCH, DObstRCOG } \\
\text { Acute/on call content } \\
5 \text { or more sessions } \\
\text { Courses/study leave } \\
\text { Research activities } \\
\text { Teaching opportunities } \\
\text { Regular review of post by member(s) of postgraduate committee locally }\end{array}$ & $\begin{array}{c}5 \\
38 \\
(36-54) \\
39 \\
(38-61) \\
4 \cdot 8 \\
2 \cdot 8 \\
3 \\
5 \\
2 \\
2 \\
3 \\
5 \\
5 \\
4 \\
3 \\
2\end{array}$ & $\begin{array}{c}4 \\
32 \cdot 5 \\
(32-41) \\
40 \cdot 5 \\
(34-46) \\
6 \cdot 3 \\
4 \cdot 1 \\
4 \\
4 \\
0 \\
0 \\
1 \\
4 \\
2 \\
3 \\
2 \\
3\end{array}$ & $\begin{array}{c}13 \\
36 \\
(31-55) \\
41 \cdot 5 \\
(38-48) \\
6.3 \\
2 \cdot 8 \\
11 \\
12 \\
1 \\
8 \\
7 \\
13 \\
9 \\
3 \\
2 \\
8\end{array}$ & $\begin{array}{c}8 \\
35 \\
(31-44) \\
41.5 \\
(38-50) \\
4.2 \\
1.5 \\
4 \\
5 \\
2 \\
2 \\
0 \\
7 \\
6 \\
3 \\
2 \\
4\end{array}$ & $\begin{array}{c}30(64 \%) \\
36.5 \\
(31-55) \\
41 \cdot 0 \\
(34-61) \\
5.5 \\
3.5 \\
22 \\
26 \\
5 \\
12 \\
11 \\
29 \\
22 \\
13 \\
9 \\
17\end{array}$ \\
\hline
\end{tabular}

- Whole time equivalent. 
TABLE V-Part time registrars' and senior house officers' personal questionnaires

\begin{tabular}{|c|c|c|c|c|c|}
\hline & $\begin{array}{l}\text { General (internal) } \\
\text { medicine and } \\
\text { subspecialties }\end{array}$ & Geriatrics & Paediatrics & $\begin{array}{l}\text { Dermatology and } \\
\text { venereology }\end{array}$ & Total \\
\hline $\begin{array}{l}\text { No of replies } \\
\text { Age now (median) (range) }\end{array}$ & $\begin{array}{c}6 \\
35 \cdot 5\end{array}$ & $\begin{array}{c}8 \\
31 \cdot 5\end{array}$ & $\begin{array}{l}18 \\
34\end{array}$ & $\begin{array}{l}10 \\
34\end{array}$ & $42\left(45^{\circ}{ }^{\circ}\right)$ \\
\hline Ace at completion of 3 year WTF general nrofescional training & $(34-41)$ & $(26-52)$ & $(28-45)$ & $(30-53)$ & $(26-53)$ \\
\hline Age at completion of 3 year WTE general professional training & $\begin{array}{c}40 \\
(37-44)\end{array}$ & $\begin{array}{c}35 \\
(30-52)\end{array}$ & $\begin{array}{c}35 \cdot 5 \\
(29-49)\end{array}$ & $\begin{array}{l}40 \cdot 5 \\
(32-55)\end{array}$ & $\begin{array}{c}37.5 \\
(29-55)\end{array}$ \\
\hline MRCP part 1 & 0 & $\frac{1}{2}$ & 2 & 2 & 5 \\
\hline Other qualification-for example, $\mathrm{DCH}$ & 1 & 0 & 8 & 5 & 14 \\
\hline Appointed by an advisory appointments committee & 4 & 2 & 4 & 2 & 12 \\
\hline Present post viewed as giving necessary experience & 3 & 4 & 16 & 10 & 33 \\
\hline Lack of acute/on call or unsuitable for MRCP & $\frac{1}{5}$ & 7 & 11 & 1 & 20 \\
\hline $\begin{array}{l}5 \text { or more sessions } \\
\text { Courses/study leave }\end{array}$ & $\begin{array}{l}5 \\
3\end{array}$ & 1 & $\begin{array}{l}18 \\
14\end{array}$ & $\begin{array}{l}9 \\
6\end{array}$ & $\begin{array}{l}39 \\
24\end{array}$ \\
\hline Teaching opportunities & 0 & 0 & 3 & 0 & 3 \\
\hline Review of post by educational adviser & 3 & 6 & 11 & 5 & 25 \\
\hline
\end{tabular}

Career intentions: consultant (8); consultant but might be associate specialist (6); associate specialist (7); general practice (7); uncommitted or clinical assistant (14)

* Whole time equivalent.

medical training and who should have been placed in their career posts. They were not subject to any regular review (table IV). In at least three regions these posts have no regular review by the postgraduate committee like that of full timers, and we found no evidence of a college review of time expired part time senior registrars.

The impression is left of a highly able group of senior registrars attempting a difficult and sometimes unreliable training route to consultant standard. It is clearly possible, though very demanding, to achieve this training. Even for those who do, some comment on their prospects is necessary.

Prospect of a consultant post is clearly better in shortage specialties, but there are other factors. The age at which these senior registrars will complete their higher medical training is not so much greater than that of full time senior registrars as might have been expected (table IV). This is largely explained by their having delayed going part time until they had adequate experience, as the table shows. But a much more important limitation is the geographical immobility of the senior registrars tied to their own region or even area by their home commitments (spontaneously mentioned by five of the 30 as the main problem); and the same constriction may compel them (four spontaneous mentions) to do their career post part time, at least initially. If ways of creating part time career, as opposed to training, posts are not found the nation risks a serious wastage of able medical womanpower, and the laudable training objectives of $\operatorname{PM}(79) 3$ will have no outlet. In the old days part time consultants were considered to be quite acceptable on firms usually with a full time director; the alternatives to this historical precedent seem to be to negate part time training or to generate another paraconsultant grade.

\section{PART II: REGISTRARS AND SENIOR HOUSE OFFICERS}

Here the outlets from the training are more varied, but the selection of applicants for and training content of the posts is haphazard and deficient.

The survey finally verified 93 such posts (table I), and the figures show the great regional variation in the availability of part time posts, which was a feature of the trainees' comments.

The specialty distribution (table II) reflects the same popularity of paediatrics as with the senior registrars, but in addition there are a sizable number of posts in geriatrics and in dermatology and venereology. We consider this distribution to be a reflection of the fact that, unlike its provision for senior registrars, PM(79)3 merely states for registrars and senior house officers that employing authorities are "free to establish personal part time posts without central approval." The assumed expansion, unregulated, of the part time registrar and senior house officer grades contrasts with the proposed reduction of the full time ones and is one reason for the supernumerary nature of the posts, which we discuss below. Manpower authorities, however, will find it hard to calculate the need for posts, as some part timers are training for posts as associate specialist or clinical assistant (part time medical officer), as well as general practice (table V).

Fewer than one third of these appointments were made at a formal appointments committee (table III, from RA's returns). This informality in the appointment procedure is confirmed by the trainees: only 12 of the 42 responding trainees had been appointed by an advisory appointments committee (table V), though another six "didn't know." It leads to a suspicion by their colleagues that part time registrars and senior house officers are in some way disreputable, and needs action. In our view an advisory appointments committee should be held to ensure that the proposed programme is suitable and relevant to the appointee's needs, which means strong educational representation on it.

The training content of the posts was highly variable, and in no sense can many of these posts be said to give the same sort of experience (if slower) as corresponding full time ones. Two thirds had not been inspected for general professional training (table III), and of the ones that had been visited more than half had been refused educational approval. This may not matter for those planning to be part time medical officers (clinical assistants) or some associate specialists, but it is a great disadvantage to the hopes of those aiming in other directions. One of the reasons for non-inspection is that personal posts may be created ad hoc between general professional training visits to a particular hospital, and arrangements should be made to get over this.

Even for some of those who regarded their posts as satisfactory, the main deficiency was acquisition of acute or on call experience or both (table V). Reasons ranged from obstruction by consultants or other colleagues to saturation of a service by people requiring experience, so that the part timers got shut out, or excessive domestic commitment. For those hoping to complete their general professional training part time, either because they hope to be senior registrars or in order to keep their options open, these part time posts seem most unsuitable. In the sessional specialties of dermatology and venereology, and possibly some others like clinical pharmacology, this is not so much of a problem. For those in vocational training for general practice, or aiming to be associate specialists or part time medical officers, who may be filling in specific gaps in their training for a specific purpose, the training content may be suitable. But half the posts were considered unsuitable for the MRCP (table V). One way of improving this would be to split some full time posts into two part time ones, but this could be done only in big centres because a consultant thus disestablishing a full time post may later find himself stranded if there happens not to be a supply of part timers awaiting a local vacancy.

This lack of acute experience is compounded by the posts not 
being reviewed regularly (tables III and V). Some trainees may thus remain in a happy state of illusion about their real progress. It is arguable whether a 52 year old registrar in geriatrics is really training, for example, and should move to associate specialist or part time medical officer status. Nine of the 42 replying had already completed the equivalent of three years' whole time equivalent general training and were "parked" at ages between 29 and 52 . They should move on to their general practice or senior registrar training posts, or sideways to part time medical officer or associate specialist. Regular review should be a feature of these posts to prevent the problems of "time expired" doctors in inappropriate "training" posts.

Even for those with satisfactory training programmes daunting problems remain for the postholders' careers. As with senior registrars, chief of these are geographical immobility and domestic commitment, which we discuss more fully in another paper. No amount of training can overcome this. Another handicap is age (table V). It would seem unrealistic to expect someone who will not finish higher medical training till her late 40 s to achieve a consultant post in competition at that age. Prudent advice to anyone who cannot complete part time general professional training by age 40 (or maybe less) is that they should not think in terms of going on to higher training.

\section{Conclusion}

Part time training for senior registrars may be a highly satisfactory means of enabling talented and determined doctors with domestic commitment or other handicap to train to consultant standing, though the arrangements need attention. Part time training at registrar and senior house officer level, however, is mainly suited to general practice, associate specialist, or clinical assistant careers and is particularly difficult in acute specialties. The arrangements are seriously deficient. The college could help to rectify some of these organisational problems but has an equally important role in education. The ignorance of the mechanisms and problems of part time training in general medical subspecialties is something that the college can help with now it has some facts. Furthermore, the college could usefully work in concert with other colleges whose disciplines present perhaps different problems in part time training.

\section{Recommendations}

\section{SENIOR REGISTRARS}

(1) The relevant manpower authorities should be made aware of the numbers of part time senior registrars in training, including the majority appointed before the manpower regulation of $\operatorname{PM}(79) 3$, and especially in paediatrics.

(2) The appointments procedures need strengthening in the following ways.

(i) The enforcement of appointment by a properly constituted advisory appointments committee.

(ii) This advisory appointments committee should have statutory college representation to bring the educational advice and assessment of an applicant's previous training to the same standard as for full time posts (as required in PM(79)3).

(iii) The college representative should be charged by the college with ensuring that the advisory appointments committee exercises the same criteria as for tull time posts, as $\operatorname{PM}(79) 3$ requires.

(3) (i) The college should provide a list of specialties in which part time senior registrar training is easiest-for example, the "sessional" specialties. of dermatology and venereology, and others such as clinical pharmacology.

(ii) In doing so the college should advise intending part time senior registrars to delay entering part time training until they have the maximum possible acute experience where this is relevant to the specialty. (iii) The college would with benefit cause its regional advisers to be more concerned (by both employing authorities and aspiring senior registrars) in preappointment counselling of those intending to do part time senior registrar training in acute specialties, with reference to both the acute experience available in the proposed post and the trainee's ability to undertake it, and the proposed consultant's ability to provide it.

(4) The college should press the meeting of postgraduate deans to be sure that its senior registrar regional subcommittees review part time senior registrars each two years in their eight year post, and the college should itself apply the same reviews to time expired part time senior registrars as it does to full time ones.

(5) The college should seek ways and means of creating part time consultant posts in all medical specialties, as well as in sessional specialties such as dermatology and venereology.

\section{REGISTRARS}

(1) The relevant manpower authorities should be made aware of the number of part time registrars and senior house officers in training in medical subspecialties. While these posts should be subject to the same manpower regulation as full time posts, this should be with the objective of serving additional subsequent outlets besides higher medical training and general practice, namely the associate specialist and part time medical officer grades.

(2) An advisory appointments committee should be held by the regional postgraduate dean for all seeking appointment as registrar or senior house officer under $\mathrm{PM}(79) 3$. This committee should satisfy itself that: $(i)$ the appropriate regional adviser considers that the proposed personal training programme is likely to be approved for general professional training, or is otherwise suitable to the applicant's needs; (ii) that the standing of the applicant is such that he or she would have been shortlisted for an equivalent full time post if able to undertake one; or (iii) the post is otherwise appropriate.

(3) (i) Regional advisers should ensure that $P M(79) 3$ registrar and senior house officer posts are included in general professional training visits, or otherwise have them visited soon after the post starts.

(ii) The committee on general professional training should facilitate this by setting up a "flying squad," which could rapidly, even informally, visit small numbers of $P M(79) 3$ posts between major general professional training inspections at the request of a college regional adviser.

(4) Regional advisers should have a more extensive role in counselling employing authorities and doctors seeking $\operatorname{PM}(79) 3$ registrar and senior house officer posts that:

(i) These posts are seldom a satisfactory method of acquiring general professional training, except in such specialties as dermatology and venereology.

(ii) Trainees wishing to enter acute specialties should delay going part time until they have sufficient acute experience.

(iii) $\operatorname{PM}(79) 3$ registrar and senior house officer posts are generally suitable for vocational training, or for those hoping to become associate specialists or part time medical officers.

(5) Consultant physicians should be prepared to consider splitting full time registrar or senior house officer posts into two PM(79)3 ones, where this is consistent with clinical service, an adequate supply of suitable part time applicants exist, and the employing authority can guarantee that the post will not be lost if the part time arrangements fail.

(6) That it be compulsory for employing authorities to have personal PM(79)3 registrar and senior house officer posts reviewed annually and on other occasions as necessary by the regional adviser and postgraduate dean.

(7) Applicants for PM(79)3 registrar and senior house officer posts who will not be able to complete three years' whole time equivalent general professional training by the age of 40 should 
be told before appointment that they will be considered for later part time senior registrar training only in exceptional circumstances.

\section{General recommendations}

(1) (i) The college should seek to counsel young graduates by presenting information on the following:

(a) The requirements for general professional training in the various subbranches of general medicine.

(b) The specialties best suited and least suited to part time training, the sessional specialties of dermatology and venereology being the best and the acute specialties the least. (c) The desirability of continuing full time training until general professional training is complete, unless a career as an associate specialist or in general practice is planned.

(d) The availability of advice on part time training from regional advisers. This information should be made available to graduates at the time of full registration with the General Medical Council.

(ii) This counselling role would with advantage be done in concert with the other colleges, and it should be considered whether an intercollegiate working party on part time training and careers would be helpful.

(Accepted 20 fuly 1983)

\title{
Outside Europe
}

\section{Working in Afghanistan}

\author{
CHRIS BLATCHLEY
}

Five years ago I visited Afghanistan as a tourist. I returned last September as a doctor to help with the emergency medical relief sent to rural areas by the French organisation Médecins sans Frontières. Now the country was at war I had little idea what to expect. Afghan guerilla groups were fighting each other in some areas and, though this did not concern us directly, it might have made it impossible for us to stay; we could not have worked impartially. Because of poor communications and volatile politics we could only assess conditions once we had arrived. Three hundred miles of dirt tracks by jeep led us to the Hazarat mountain region, 150 miles south west of Kabul, inhabited by people descended from Mongolian invaders. We had no direct contact with the Russians as the government controls mostly urban areas and our route avoided these.

I was working with two women doctors and a male nurse in the remote mountains at over 10000 feet. We lived in one room of traditional mud construction. There was no electricity, and we carried our drinking water from the stream 50 yards away. We worked in one large consulting room, using a curtain to divide the men from the women. Some of the 200 patients a day had walked for eight days to reach us. We had only the simplest diagnostic aids, with no $x$ ray facilities or blood tests, but we did have a remarkably well equipped pharmacy. Some of the medical teams had worked in active war zones and treated trauma, but while I was there my area was largely peaceful.

The medical problems were mainly those seen in a primitive mountain region, influenced by poor hygiene, low incomes, and inadequate diet. It was difficult to estimate how the Russian occupation had changed things. People were poorer because of $100 \%$ annual inflation and because sons could no longer work abroad. In my area there were enough people to tend the land

St Joseph's Hospice, Mare Street, London E8 4SA CHRIS BLATCHLEY, MB, BCH, senior house officer

Correspondence to: Medical Action, 3 Park Square West, London NW1. and they grew crops without interference from the Russians. There was only just enough land to support them.

There was a huge gap, however, between the rich and the poor. The richest lived in large spacious houses and kept themselves clean with Palmolive soap, bought from the bazaar. They had simple lavatories, though, which were usually perilously close to streams. They had enough land to support many animals and so ate a lot of meat. They supplemented their diets with the crops that they took as rent from tenant farmers. They had a good life expectancy-many reaching their three score years and ten.

The poorest had to pay half or more of their scanty harvest as rent and had to work the inferior land extremely hard for little return. Their homes were grossly overcrowded. They ate

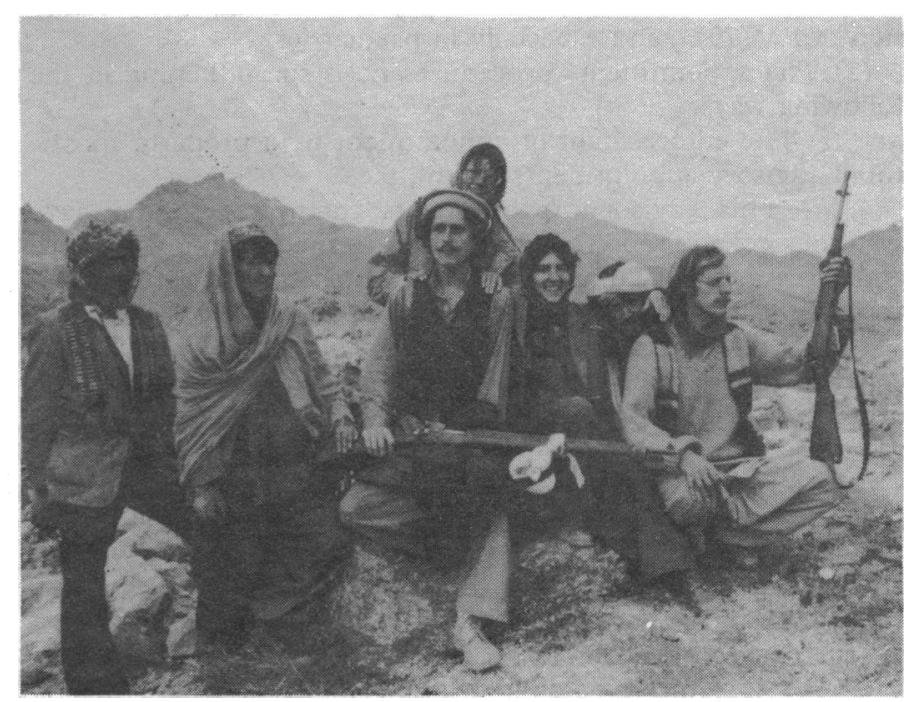

Some of the Medecins sans Frontières team with thcir mujahideen escorts. 